\title{
Method Development to Increase Protein Enrichment During Dry Fractionation of Starch-Rich Legumes
}

\author{
Pascalle J. M. Pelgrom ${ }^{1}$ - Remko M. Boom ${ }^{1}$ • Maarten A. I. Schutyser ${ }^{1}$
}

Received: 12 January 2015 / Accepted: 23 March 2015 / Published online: 8 April 2015

(C) The Author(s) 2015. This article is published with open access at Springerlink.com

\begin{abstract}
A facile method was developed to establish milling settings that optimally separate starch granules from protein bodies and cell wall fibres for starch-rich legumes. Optimal separation was obtained for pea, bean, lentil and chickpea when the particle size distribution curve of flour and isolated starch granules overlap maximally. This outcome was based on scanning electron microscopy, protein content of the fine fraction and particle size distribution curves. Milling settings differed between legumes due to variances in seed hardness and starch granule size. The protein content of the fine fraction was legume specific as well and could be explained by differences in particle density, seed hardness, starch granule size, fat content and flour dispersibility.
\end{abstract}

Keywords Milling $\cdot$ Air classification $\cdot$ Protein concentrates · Morphology $\cdot$ Legumes

\section{Introduction}

Interest in legume proteins has increased in recent years due to their nutritional and functional properties and for sustainability reasons (Boye et al. 2010; Day 2013). Legume protein concentrates are low in fat and are excellent sources of protein, dietary fibre and a variety of micronutrients and phytochemicals (Messina 1999; Boye et al. 2010). These protein have been used in food products for their solubility or their gelation

Maarten A. I. Schutyser

maarten.schutyser@wur.nl

1 Laboratory of Food Process Engineering, Wageningen University, P.O. Box 17, 6700 AA Wageningen, The Netherlands and dough formation capacity (Day 2013). Moreover, consumption of legume proteins instead of animal protein would lead to a more efficient and more sustainable food supply (Aiking 2011; González et al. 2011).

Wet fractionation is conventionally used to purify plant proteins; however, this process uses large amounts of water and energy. Furthermore, the native functionality of the proteins is lost due to $\mathrm{pH}$ changes and elevated temperatures during dehydration (Schutyser and Van der Goot 2011). An alternative process to enrich plant proteins is dry fractionation, which is carried out by milling and air classification. Milling detaches the starch granules from smaller protein-rich particles. During subsequent air classification, the starch granules and protein fragments are separated on their difference in density and size.

Legumes that have been subjected to dry fractionation are peas, mung beans, lentils, common beans, faba beans, navy beans, lima beans and cowpeas. Their protein enrichment is facilitated by the size difference between protein-rich particles (approx. $5 \mu \mathrm{m}$ ) (Pernollet 1978) and starch granules (approx. 15-40 $\mu \mathrm{m}$ ) (Hoover et al. 2010). The protein content of the fine fraction varies between $49 \mathrm{~g} / 100 \mathrm{~g}$ dry matter for lima beans and $70 \mathrm{~g} / 100 \mathrm{~g}$ dry matter for faba beans (Sosulski and Youngs 1979; Elkowicz and Sosulski 1982; Tyler et al. 1981). Protein enrichment is enhanced by larger starch granule size (Cloutt et al. 1987; Tyler 1984).

To obtain maximum protein enrichment, the degree of milling should be such that starch granules and protein are detached. However, very fine milling is not optimal for air classification; the non-protein components, like starch and fibre, should remain larger than the protein bodies (Pelgrom et al. 2013). A better understanding of the particle size distribution in relation to detachment would enable us to predict protein enrichment after air classification and to extent knowledge on milling of pea to a wider range of starch-rich legumes. 
In this study, milling is optimised towards maximum detachment of starch granules, in contrast to previous studies in which all legumes were milled at a single setting (Cloutt et al. 1987; Sosulski and Youngs 1979; Tyler 1984). We explore the hypothesis that optimal detachment is reached when the particle size distribution curve of flour overlaps maximally with the particle size distribution curve of the starch granules. The added value of this hypothesis is that optimal milling conditions and thus detachment settings for a specific starch-rich legume can be obtained easily, thereby facilitating protein enrichment of these crops by subsequent air classification.

Although our hypothesis is based only on maximum overlap between starch granule and flour size, other factors have been reported to influence optimum detachment as well. Tyler (1984) described that the protein separation efficiency (PSE), defined as the proportion of the total flour protein shifted into the fine fraction during air classification, was negatively correlated to seed hardness, crude fibre content and water-insoluble cell wall content of the seed. In contrary to Tyler (1984), Wu found that the separation efficiency improved for softer wheat seeds (Wu and Stringfellow 1992). The relation between crude fibre content and protein separation efficiency is debatable as well, as other measures for the amount of cell wall material, like neutral detergent fibre content and cell wall thickness, were not related to protein separation efficiency. Next to that, Tyler (1984) reported that levels of protein, starch and ash had little or no effect on the impact milling characteristics of the legumes, while the protein content in pea was positively correlated with the protein content in air-classified fractions (Reichtert 1982). Another factor that influences the separation efficiency of legumes is the amount of oil present. Due to the higher amounts of oil, chickpea, lupine and soy have been reported to be unsuitable for dry fractionation (Elkowicz and Sosulski 1982; Sosulski and Youngs 1979). Despite the presence of oil, we were recently able to enrich lupine flour in protein by adapting the milling settings to the seed morphology (Pelgrom et al. 2014).

Concluding, although maximum overlap is proposed as route for optimal detachment, it does not cover all aspects that determine optimal milling conditions of legumes and subsequent effective separation. Therefore, four starch-rich legumes, i.e. pea, bean, chickpea and lentil, were extensively characterised and their properties were correlated to results of the dry separation. First, the composition of the legumes, their morphology and starch granule size were characterised. Then, to validate our approach, legumes were milled and air classified. The fractions were tested for protein content, particle size distribution, particle density and dispersibility.

\section{Materials and Methods}

\section{Materials}

Pre-dried chickpea (Cicer arietinum), lentil (Lens culinaris), pea (Pisum sativum) and bean (Phaseolus vulgaris) were purchased from Alimex (Sint Kruis, The Netherlands) and stored in closed containers at $4{ }^{\circ} \mathrm{C}$. All materials still contained their hulls and were unheated. Experiments were done at least in duplicate.

\section{Milling, Sieving and Air Classification}

Legume were pre-milled to grits $\left(\mathrm{D}_{0.5}\right.$, the volume-averaged particle diameter, of 140-220 $\mu \mathrm{m}$ ) with a Condux-Werk LV 15 M (Condux-Werk, Wolfgang bei Hanau, Germany). The grits were milled with a ZPS50 impact mill (HosokawaAlpine, Augsburg, Germany). This mill contains an internal rotating classifier wheel that allows the passage of fine particles while coarse particles are returned and further milled. The classifier wheel speed determined, together with the air flow, the size of the milled flour. The classifier wheel was varied between 2200 and $8000 \mathrm{rpm}$ and the air flow was varied between 40 and $52 \mathrm{~m}^{3} / \mathrm{h}$. Other parameters were as follows: a feed rate of $2 \mathrm{rpm}$ (circa $0.5 \mathrm{~kg} / \mathrm{h}$ ), an impact mill speed of $8000 \mathrm{rpm}$ and a batch size of at least $600 \mathrm{~g}$.

Pea flour was separated by air jet sieving (Alpine200 LS-N, Hosokawa-Alpine, Augsburg, Germany) during $2.5 \mathrm{~min}$ at $4000 \mathrm{~Pa}$ on a $20 \mu \mathrm{m}$ sieve. Each experiment started with $9.9 \mathrm{~g}$ of flour, which was mixed with $0.1 \mathrm{~g}$ fumed silica (Aerosil ${ }^{\circledR} 200$, Azelis Netherlands B.V., Oosterhout, The Netherlands) to improve the flowability.

All flours were air classified in an ATP50 classifier (Hosokawa-Alpine, Augsburg, Germany). The air flow was fixed at $52 \mathrm{~m}^{3} / \mathrm{h}$. The classifier wheel speed was set at 5000 or $10,000 \mathrm{rpm}$. The feed rate was set at $15 \mathrm{rpm}$ (circa $1.0 \mathrm{~kg} / \mathrm{h}$ ). Per batch, at least $160 \mathrm{~g}$ flour was air classified.

\section{Compositional Analyses}

The dry matter content was determined by drying $1 \mathrm{~g}$ of sample for at least $12 \mathrm{~h}$ in an oven at $105^{\circ} \mathrm{C}$.

The protein content was analysed using Dumas analysis (Nitrogen analyzer, FlashEA 1112 series, Thermo Scientific, Interscience, Breda, The Netherlands). A nitrogen conversion factor of 6.25 was used.

The fat content was measured in a fully automated Büchi extraction system B-811 LSV (Büchi Labortechnik AG, Flawil, Switzerland). Fat extraction was performed with petroleum ether (boiling range $40-60{ }^{\circ} \mathrm{C}$ ) in Standard Soxhlet mode for $3 \mathrm{~h}$ with a sample-to-solvent ratio of 1:6. 


\section{Particle Analyses}

The particle size distribution of the samples was determined by laser diffraction using a Mastersizer 2000 equipped with a Scirocco 2000 dry dispersion unit (Malvern Instruments, Worcestershire, UK). Pressure of $400 \mathrm{kPa}$ was used and the volume-weighted particle size distribution was calculated using the Fraunhofer theory.

The dispersibility of the flours was measured according to (Pelgrom et al. 2014). The ratio between the particle size at a pressure of 50 and $400 \mathrm{kPa}$ was determined using a Mastersizer 2000 equipped with a Scirocco 2000 dry dispersion unit (Malvern Instruments, Worcestershire, UK).

The scanning microscope images were obtained with a Phenom G2 Pure (Phenom-World BV, Eindhoven, The Netherlands) according to (Pelgrom et al. 2014).

The particle density of all legume grits was measured using a pycnometer (Ultrapyc 1200e, Quantachrome Instruments, Boynton Beach, USA) operating with nitrogen.

The seed hardness of all legume seeds was determined according to Pelgrom et al. (2015b). Twenty cotyledons per legume were, flat-side down, compressed by a $15 \mathrm{~mm}$ cylindrical probe attached to a Texture Analyser (Instron5564Series-Table-Model- Systems-Twin-column-design, Canton, USA) equipped with a $2000 \mathrm{~N}$ load cell at a crosshead speed of $20 \mathrm{~mm} / \mathrm{min}$.

\section{Starch Isolation}

Starch granules were isolated by steeping $50 \mathrm{~g}$ of the seeds in excess tap water overnight at $4{ }^{\circ} \mathrm{C}$. The seeds were milled for 2 min combined with the steep water in a domestic blender (Philips HR7776/90, Philips, Eindhoven, The Netherlands). The slurry was washed with $500 \mathrm{ml}$ tap water on a 125 and $90 \mu \mathrm{m}$ sieve. The sieving water was collected and allowed to settle for $1 \mathrm{~h}$ at $4{ }^{\circ} \mathrm{C}$. The white bottom layer was collected and re-dispersed in $100 \mathrm{ml}$ tap water. The suspension was centrifuged for $20 \mathrm{~min}$ at $3000 \mathrm{~g}$ after which the supernatant and a non-white layer were removed. The white bottom layer was dispersed again in $100 \mathrm{ml}$ tap water and the centrifugation procedure was repeated two times. Part of the pellet was dried in a vacuum oven at $40{ }^{\circ} \mathrm{C}$ overnight. The other part was suspended in tap water and stored for particle size distribution analysis.

The particle size distribution of starch granule suspensions was analysed by laser diffraction using a Mastersizer particle size analyser (Malvern Instruments Ltd. 2000, Worcestershire, UK) according to Pelgrom et al. (2015a).

The total starch content of isolated starch from the four legumes was determined using a Total Starch Amyloglucosidase/a-Amylase Assay Kit (Megazyme International Ireland Ltd, Bray, Ireland). The starch isolate contained 92 to $96 \mathrm{~g} \mathrm{starch} / 100 \mathrm{~g}$ dry matter.

\section{Statistical Analysis}

Student's $t$ tests were performed to evaluate the differences between fractions. Differences were considered to be significantly different when the $p$ value was smaller than 0.05 .

\section{Results and Discussion}

The particle size distribution (PSD) curves of pea flours and wet isolated starch were first analysed to explore the hypothesis that optimal detachment is reached when the overlap between the particle size distribution curve of the starch granules and that of the pea flour is maximal. The overlap for pea is maximal at a classifier wheel speed of $4000 \mathrm{rpm}$ during milling (Table 1).

The hypothesis that this is an indicator for optimal detachment of the starch granules from the protein matrix and the cell wall fibre was confirmed by assessing the composition of the particles smaller than $20 \mu \mathrm{m}$ by sieving (Table 1). Milling seeds at $2500 \mathrm{rpm}$ created insufficient detachment, while flour milled at $8000 \mathrm{rpm}$ had similar protein content of particles smaller and larger than $20 \mu \mathrm{m}$ due to the small size of the flour particles, and thus showed no potential for separation.

The optimal milling settings are in agreement with previous settings for milling and air classification of pea (Pelgrom et al. 2013) obtained by trial and error.

The hypothesis is further evaluated for bean, chickpea and lentil in the next section.

\section{General Comparison of the Four Legumes}

Figure 1 shows that the cotyledon architectures of the four legumes are similar. Starch granules (S) are embedded in a matrix of protein bodies $(\mathrm{P})$ and are surrounded by a fibre-rich cell wall $(\mathrm{CW})$. The starch granules of pea, bean and lentil are around $25 \mu \mathrm{m}$, while chickpea starch granules are smaller with a size of $18 \mu \mathrm{m}$ (Table 2), which is in agreement with literature (Hoover and Ratnayake 2002). Other differences between the legumes were the higher overall protein content of bean $(p<0.05)$ and the higher fat content of chickpea $(p<0.05)$ (Table 2).

The $\mathrm{D}_{0.5}$, the volume-averaged particle diameter, of bean and lentil after milling at fixed settings were significantly

Table 1 The effect of classifier wheel speed during milling on flour size and protein enrichment of pea \pm absolute deviation $(n=2)$ (Pelgrom et al. 2013)

\begin{tabular}{llll}
\hline $\begin{array}{l}\text { Classifier } \\
\text { wheel speed } \\
(\mathrm{rpm})\end{array}$ & $\begin{array}{l}\mathrm{D}_{0.5} \\
(\mu \mathrm{m})\end{array}$ & $\begin{array}{l}\text { Overlap with starch } \\
\text { granule curve }(\%)\end{array}$ & $\begin{array}{l}\text { Protein enrichment } \\
\text { particles }<20 \mu \mathrm{m}(\%)\end{array}$ \\
\hline 2500 & $19.3 \pm 0.7$ & $58.1 \pm 1.0$ & $35.6 \pm 9.1$ \\
4000 & $17.9 \pm 0.7$ & $63.2 \pm 2.2$ & $51.3 \pm 3.7$ \\
8000 & $8.0 \pm 0.1$ & $21.5 \pm 0.9$ & $-2.9 \pm 1.8$ \\
\hline
\end{tabular}




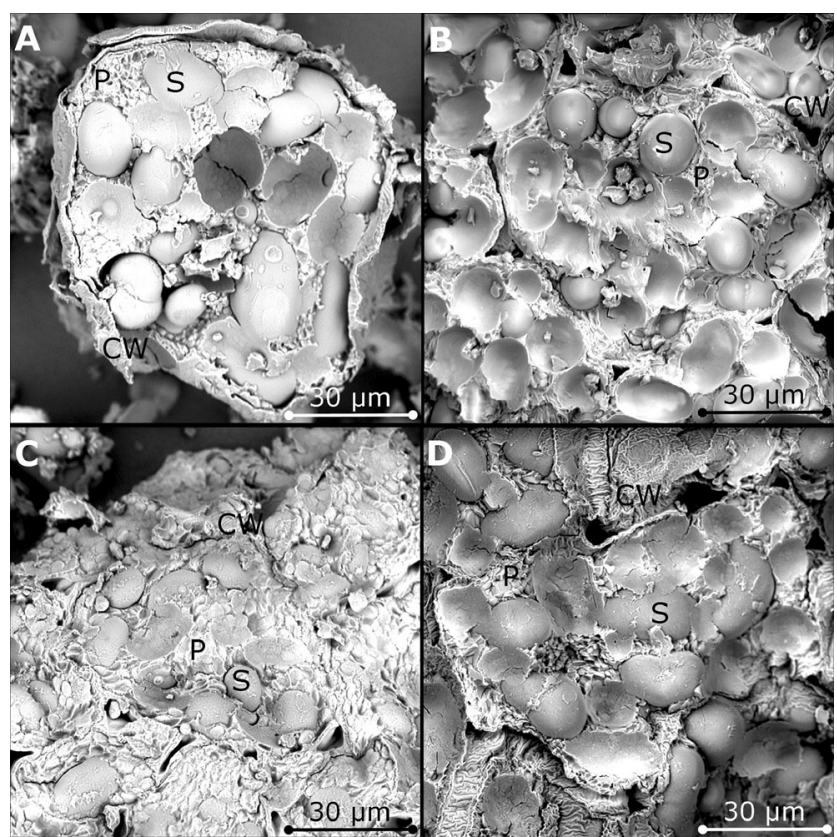

Fig. 1 Morphology of pea (a), bean (b), chickpea (c) and lentil (d). Starch granules $(S)$, protein bodies $(P)$ and cell wall $(C W)$ can be distinguished

$(p<0.05)$ lower than that of pea (Table 2). This can be explained by the lower seed hardness of bean and lentil (Table 2). The $\mathrm{D}_{0.5}$ of chickpea was similar to that of pea; however, the starch granules of chickpea are smaller. Thus, to obtain maximum overlap between the particle size distribution of starch granules and milled flour, more intensive milling is expected to be needed.

\section{Optimal Enrichment Following the Maximum Overlap Hypothesis}

The milling settings and specifically the settings of the classifier wheel were adjusted to obtain optimal detachment for all four legumes, which corresponded to the maximum overlap of the particle size distribution of the milled flour and that of the starch granules (Fig. 2). The air flow was kept constant at a value of $40 \mathrm{~m}^{3} / \mathrm{h}$, since at this air flow rate, the width of the particle size distribution of the flour was smallest.
Figure 2 shows that the average particle size and the width of the size distribution decreased at higher classifier speeds. The detachment at milling settings with maximum overlap in particle size distribution curves was analysed by scanning electron microscopy (SEM; Fig. 3). The starch granules and smaller (probably protein matrix) fragments were separate particles and were not linked anymore.

Subsequently, the flours with maximum overlap were subjected to air classification.

Air classification was performed at settings that provided a fine fraction with a smaller average particle size $\left(D_{0.5} 5.9 \mu \mathrm{m}\right.$, $\left.\mathrm{D}_{0.9} 17.0 \mu \mathrm{m}\right)$ than the average size of the starch granules $\left(D_{0.5} 23.7 \mu \mathrm{m}, D_{0.1} 15.4 \mu \mathrm{m}\right)$ (Table 3). Thus, we assumed that the fine fraction contained little starch. This assumption can only be made when flour is not milled smaller than the size of the starch granules. The low particle size of the fine fraction led to a protein content which was in agreement with the maximum protein contents reported in literature (Elkowicz and Sosulski 1982; Sosulski and Youngs 1979; Tyler et al. 1981). Moreover, the particle size distribution curve of the fine fraction confirmed that smaller, protein-rich fragments were effectively separated (Fig. 4). The particle size distribution curves show as well that insufficiently milled flour provided a smaller peak at $5 \mu \mathrm{m}$ and gave a lower yield after air classification, but similar protein content (for example $52.9 \mathrm{~g} /$ $100 \mathrm{~g}$ dry bean fine fraction). Too fine milled flour contained more particles of around $5 \mu \mathrm{m}$, which probably are finely milled fibres and broken starch granules. As a result, this lowered the protein content of the fine fraction slightly (for example $57.4 \pm 0.9 \mathrm{~g} / 100 \mathrm{~g}$ dry lentil fine fraction compared to $58.5 \pm 0.2 \mathrm{~g} / 100 \mathrm{~g}$ dry lentil fine fraction (Table 3)).

Therefore, it can be concluded that the maximum overlap hypothesis provides optimal dry fractionation. However, the differences between the fine fraction protein contents of the different types of legumes cannot be explained by the hypothesis as these are also function of the material properties.

\section{Legume Properties That Co-Determine the Dry Enrichment of Proteins}

In this section, the material properties of the four legumes are related to the milling and air classification results. Detachment

Table 2 Properties of the four legumes that may be of influence to the detachment and subsequent protein enrichment of the legumes

\begin{tabular}{|c|c|c|c|c|c|c|c|}
\hline Legume & $\begin{array}{l}\text { Starch granule } \\
\text { size }(\mu \mathrm{m})\end{array}$ & $\begin{array}{l}\text { Protein content } \\
\text { (g/100 g dry matter) }\end{array}$ & $\begin{array}{l}\text { Fat content } \\
\text { (g/100 g dry matter) }\end{array}$ & $\begin{array}{l}\text { Moisture content } \\
\text { (g/100 g sample) }\end{array}$ & $\begin{array}{l}D_{0.5} \\
(\mu \mathrm{m})\end{array}$ & $\begin{array}{l}\text { Seed } \\
\text { hardness }(N)\end{array}$ & $\begin{array}{l}\text { Particle density } \\
\left(\mathrm{kg} / \mathrm{m}^{3)}\right.\end{array}$ \\
\hline Pea & $25.8 \pm 0.5$ & $23.7 \pm 0.8$ & $1.9 \pm 0.3$ & $12.6 \pm 0.4$ & $17.1 \pm 0.8$ & $210 \pm 23$ & $1441 \pm 4.5$ \\
\hline Bean & $25.0 \pm 0.6$ & $29.8 \pm 1.4$ & $2.0 \pm 0.2$ & $12.7 \pm 0.1$ & $14.9 \pm 0.2$ & $126 \pm 13$ & $1427 \pm 2.7$ \\
\hline Chickpea & $18.9 \pm 0.1$ & $21.6 \pm 0.9$ & $6.6 \pm 0.2$ & $11.7 \pm 0.1$ & $16.1 \pm 0.4$ & $197 \pm 28$ & $1408 \pm 2.8$ \\
\hline Lentil & $25.1 \pm 0.8$ & $24.9 \pm 0.3$ & $2.1 \pm 0.0$ & $11.9 \pm 0.8$ & $12.4 \pm 0.8$ & $31 \pm 18$ & $1437 \pm 0.6$ \\
\hline
\end{tabular}

The particle size was determined after milling at a classifier wheel speed of $2900 \mathrm{rpm} \pm$ absolute deviation $(n=2)$ 

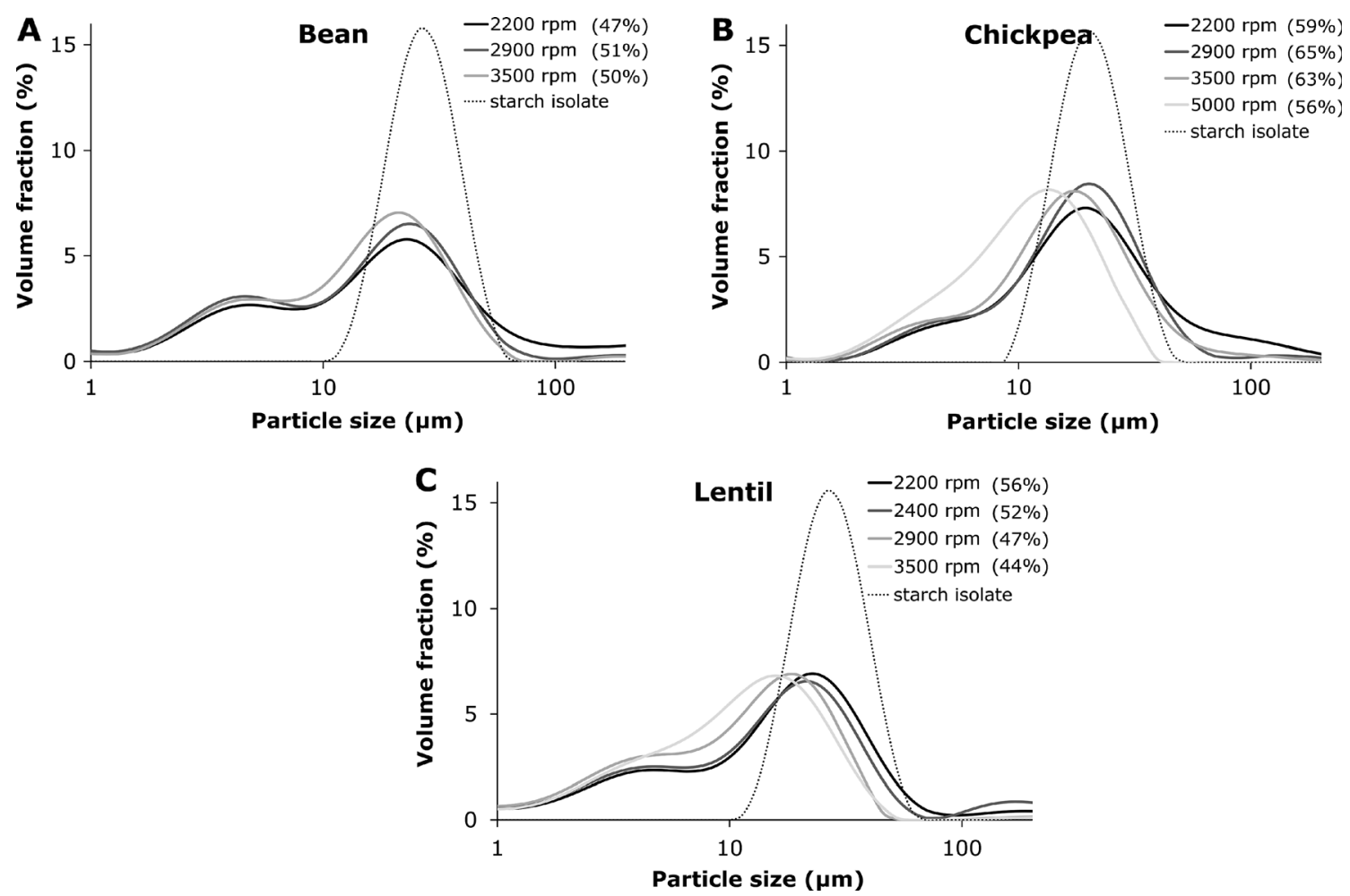

Fig. 2 Particle size distribution of bean (a), chickpea (b) and lentil (c) milled at various classifier wheel speeds and the particle size distribution of their starch granules. Next to the classifier wheel speed the percentage of overlap with the particle size distribution of the starch granules is given

of starch granules, protein bodies and cell wall during milling was evaluated using particle size distribution curves and seed hardness. Parameters that are related to the sharpness of air

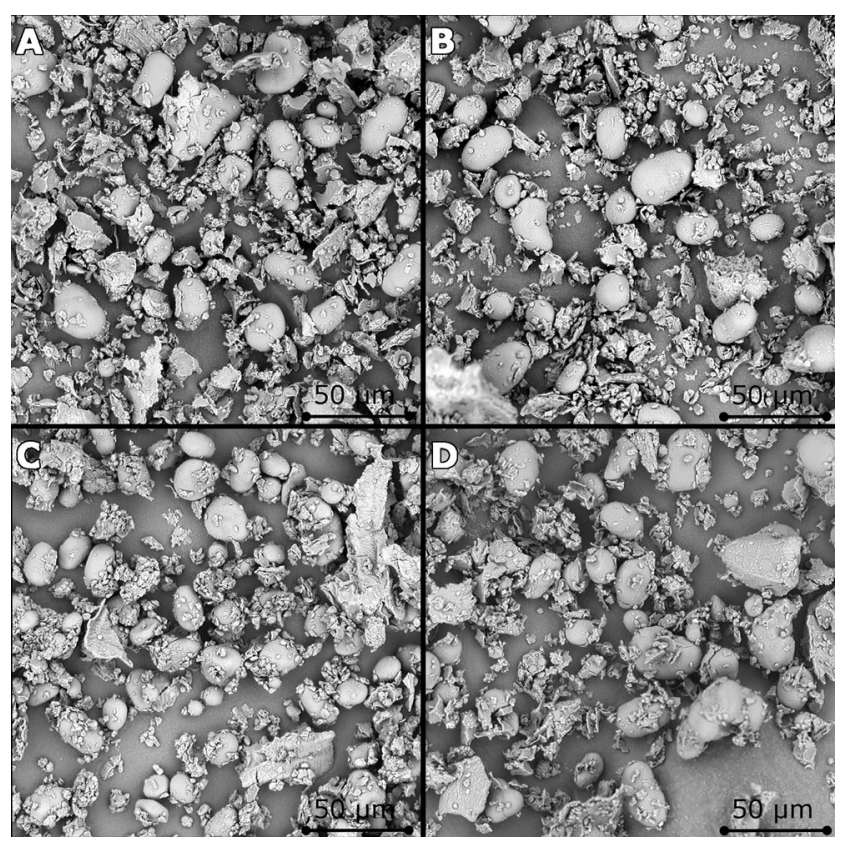

Fig. 3 Electron scanning microscope images of pea (a), bean (b), chickpea (c) and lentil (d) flour milled at settings that gave maximal overlap with the particle size distribution curve of their isolate starch granules classification are overlap in particle size distribution between the fine and the coarse fraction, particle density, starch granule and protein body size and dispersibility.

\section{Properties Related to Detachment}

The protein purity of the fine fraction decreased with increasing overlap between the particle size distribution curve of the fine fraction and the flour (Table 3). A high overlap indicates that fibre and possibly starch granules are milled too fine and may enter the fine fraction. The legumes contained around $25 \mathrm{~g}$ protein $/ 100 \mathrm{~g}$ dry matter, which meant that if the fine

Table 3 Protein content and particle size parameters of pea, bean, chickpea and lentil air classified at 10,000 rpm with an air flow of $52 \mathrm{~m}^{3} / \mathrm{h} \pm$ absolute deviation $(n=2)$

\begin{tabular}{lllll}
\hline Legume & $\begin{array}{l}\text { Protein content } \\
\text { fine fraction } \\
(\mathrm{g} / 100 \mathrm{~g} \text { dry } \\
\text { matter })\end{array}$ & $\begin{array}{l}\text { Protein content fine } \\
\text { fraction }(\mathrm{g} / 100 \mathrm{~g} \\
\text { dry matter })^{\text {literature }}\end{array}$ & $\begin{array}{l}\mathrm{D}_{0.5} \\
(\mu \mathrm{m}) \\
\text { fine }\end{array}$ & $\begin{array}{l}\text { Overlap } \\
\text { PSD fine } \\
\text { and flour } \\
(\%)\end{array}$ \\
\hline Pea & $55.6 \pm 0.5$ & $58.9 \pm 3.0$ & $5.4 \pm 0.0$ & $49.0 \pm 1.1$ \\
Bean & $52.8 \pm 0.3$ & $55.2 \pm 2.2$ & $5.1 \pm 0.1$ & $57.8 \pm 0.0$ \\
Chickpea & $45.3 \pm 0.7$ & 28.9 & $7.8 \pm 0.4$ & $61.1 \pm 2.2$ \\
Lentil & $58.5 \pm 0.2$ & $57.3 \pm 5.3$ & $5.3 \pm 0.2$ & $51.0 \pm 1.1$ \\
\hline
\end{tabular}

a (Elkowicz and Sosulski 1982; Sosulski and Youngs 1979; Tyler et al. 1981) 


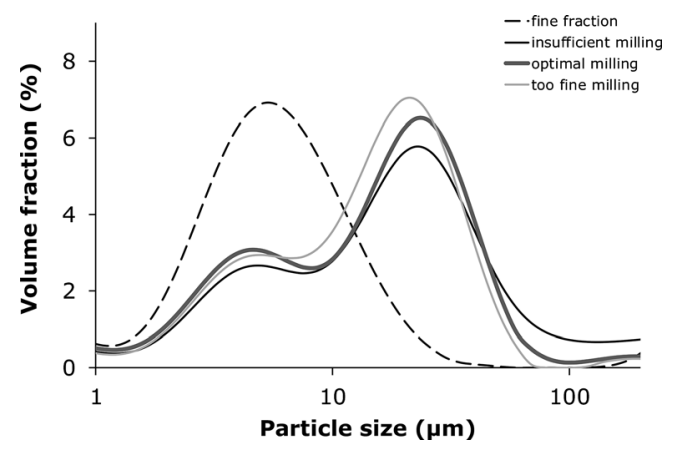

Fig. 4 Particle size distribution of flours and the fine fraction of bean

fraction would consist solely of protein, a smaller overlap than $50 \%$ would be expected. The overlap was larger for bean and chickpea because bean had to be milled smaller, and because the particle size of the fine fraction of chickpea was larger.

The higher protein content in the fine fraction may be related to the lower seed hardness of lentils (Table 2). The seed hardness is related to the adhesion between the protein matrix and starch granules (Dziki and Laskowski 2010). Next to that, seed hardness is associated with the type and amount of insoluble fibres (Wood et al. 2014). Seed hardness could thus be an indicator of the composition of particles of different sizes after milling. Tyler et al. (1981) speculated that harder seeds contain a higher level of agglomeration of starch granules and protein bodies in legumes, although he found a higher protein separation efficiency for harder legumes. In contrast, Wu and Stringfellow (1992) found higher protein separation efficiency for softer wheat varieties.

\section{Properties Related to Sharpness of Air Classification}

The overlap in particle size distribution between the fine and the coarse fraction indicates the separation sharpness. For pea, bean and lentil, the overlap was $24.5 \pm 0.8 \%$ but for chickpea, the overlap was $53.8 \pm 1.9 \%$. Chickpea thus gave less separation and $11 \%$ lower yield compared to pea, bean and lentil, which may be related to the higher fat content and low density of chickpea (Table 2) impairing air classification (Sosulski and Youngs 1979). Moreover, the chickpea starch granules were smaller providing a smaller difference in size with protein bodies $( \pm 5 \mu \mathrm{m})$, which decreased separation sharpness and caused a lower protein content in the fine fraction.

Next to that, the size of the protein bodies could be of influence. The particle size distribution of bean and lentil showed a more distinctive peak at 4-5 $\mu \mathrm{m}$ compared to pea and chickpea at all milling speeds (Figs. 2 and 5a). This peak could be related to the size of the protein bodies, which is larger for bean $(2-22 \mu \mathrm{m})$ than for pea $(1-3 \mu \mathrm{m})$ (Pernollet 1978). However, we did not observe a clear relation between protein body size and protein enrichment, probably because other differences between legumes obscured any effect of protein body size.
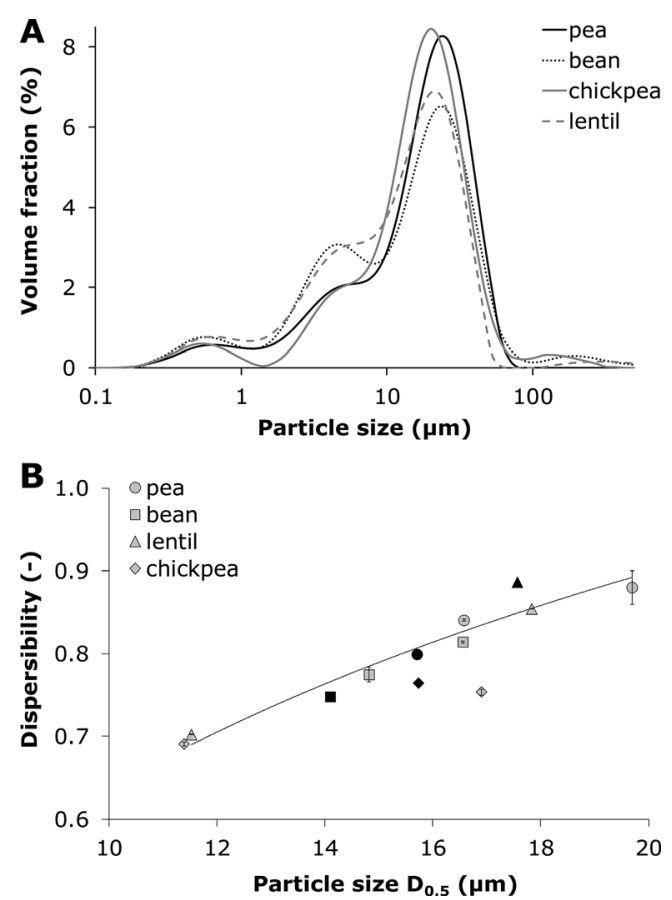

Fig. 5 a Particle size distribution of pea, bean, chickpea and lentil milled at $2900 \mathrm{rpm}$. b Dispersibility as a function of particle size of pea, bean, chickpea and lentil flour. Dark data points represent the flours that were air classified. Line is added to guide the eye \pm absolute deviation $(n=2)$

Air classification separates on the basis of particle size and particle density. The particle density of chickpea was significantly $(p<0.05)$ lower than that of pea, bean and lentil (Table 2). Consequently, larger chickpea flour particles entered the fine fraction, thereby lowering the protein content.

Finally, the dispersibility of chickpea was lower compared to pea, bean and lentil flour of similar size (Fig. 5b). The elevated fat content $(6.6 \mathrm{~g} / 100 \mathrm{~g}$ dry matter compared to $2 \mathrm{~g} / 100 \mathrm{~g}$ dry matter) may have caused the decrease in dispersibility. Moreover, the dispersibility decreased as a function of the average particle size. Lentil flour, which was most dispersible, yielded the highest protein content in the fine fraction. Bean flour, which was less dispersible than lentil and pea, yielded lower protein content in the fine fraction (Table 3).

\section{Routes to Improve Dry Enrichment of Proteins}

The parameters that influence milling and air classification of various legumes are the basis of possible routes to improve dry fractionation. Despite differences in starch granule size, protein body size, initial protein content and seed hardness, the relation between particle size and protein content was similar for all legumes (Fig. 6). This finding was in contradiction with expectations that differences in protein content of the fine fraction would be related to differences in break behaviour of the seeds, i.e. that fibres of lentil remained larger than fibres of bean. For all legumes, small particles were rich in protein. Therefore, air classification to smaller sizes in the fine fraction 


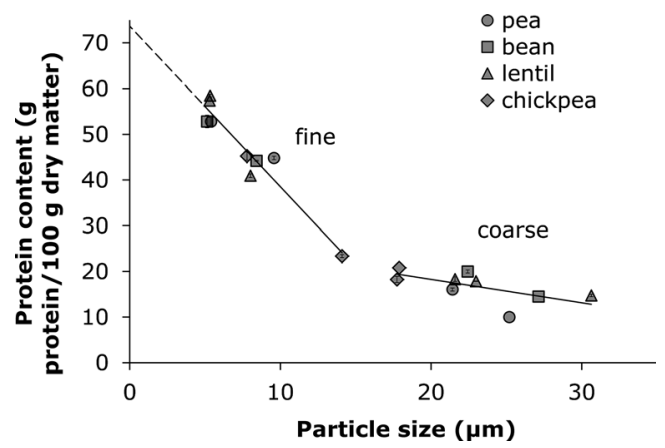

Fig. 6 Protein content as a function of particle size for air classified legumes. Lines are added to guide the eye \pm absolute deviation $(n=2)$

or sharper separation will increase the protein content, however, at the expense of the yield. Besides, milling of the fine fraction to obtain finer particles could increase the protein content, although decrease in dispersibility could impair separation. To facilitate air classification of small particles, redesign of the air classifier to decrease the amount of material build-up would be a solution.

Other routes to improve dry fractionation may be found in plant breeding or pre-treatment techniques. Plant breeding could focus on selection of varieties with larger starch granules, or tougher fibres or varieties with a lower seed hardness. The latter could contribute to easier detachment between starch granules and protein bodies, which could increase the particle size of the flour thereby increasing dispersibility and enhancing protein enrichment. Pre-treatments could also be used to accomplish these changes in legume morphology.

Figure 6 furthermore shows that extrapolation of the protein content of the fine fraction leads to a maximum of $74 \mathrm{~g}$ protein/100 g dry matter, which is in agreement with the protein content of protein bodies that is between 70 and $88 \mathrm{~g}$ protein/100 g dry matter (Plant and Moore 1983; Weber and Neumann 1980).

\section{Conclusions}

Optimal detachment was reached between starch granules and protein- and fibre-rich particles from pea, bean, chickpea and lentil by selecting those milling settings that yield the largest overlap between the particle size distribution curve of starch granules and of flour. This method is thus a facile approach to find milling settings that provide optimal detachment for starch-rich legumes. However, seed properties like seed hardness, particle density, starch granule size, fat content and flour dispersibility influence the protein content of the fine fraction as well.

It is to be expected that the maximal overlap hypothesis can be applied on a wide range of starch-rich legumes. Application on grains should also yield detachment, but subsequent air classification will probably not give large enrichments due to the small size difference between starch granules and protein bodies.

Further research could focus on pre-treatments and selection of legume varieties that possess characteristics needed for dry separation.

Acknowledgments The authors wish to thank The PEAS Foundation and ISPT for project coordination support through the Intensified Protein Structuring project (PI-00-03). We acknowledge Atze Jan van der Goot for his project support.

Open Access This article is distributed under the terms of the Creative Commons Attribution 4.0 International License (http:// creativecommons.org/licenses/by/4.0/), which permits unrestricted use, distribution, and reproduction in any medium, provided you give appropriate credit to the original author(s) and the source, provide a link to the Creative Commons license, and indicate if changes were made.

\section{References}

Aiking, H. (2011). Future protein supply. Trends in Food Science \& Technology, 22, 112-120.

Boye, J., Zare, F., \& Pletch, A. (2010). Pulse proteins: processing, characterization, functional properties and applications in food and feed. Food Research International, 43, 414-431.

Cloutt, P., Walker, A. F., \& Pike, D. J. (1987). Air classification of flours of three legume species: fractionation of protein. Journal of the Science of Food and Agriculture, 38(2), 177-186.

Day, L. (2013). Proteins from land plants-potential resources for human nutrition and food security. Trends in Food Science \& Technology, $32(1), 25-42$.

Dziki, D., \& Laskowski, J. (2010). Study to analyze the influence of sprouting of the wheat grain on the grinding process. Journal of Food Engineering, 96(4), 562-567.

Elkowicz, K., \& Sosulski, F. W. (1982). Antinutritive factors in eleven legumes and their air-classified protein and starch fractions. Journal of Food Science, 47(4), 1301-1304.

González, A. D., Frostell, B., \& Carlsson-Kanyama, A. (2011). Protein efficiency per unit energy and per unit greenhouse gas emissions: potential contribution of diet choices to climate change mitigation. Food Policy, 36(5), 562-570.

Hoover, R., \& Ratnayake, W. S. (2002). Starch characteristics of black bean, chick pea, lentil, navy bean and pinto bean cultivars grown in Canada. Food Chemistry, 78(4), 489-498.

Hoover, R., Hughes, T., Chung, H. J., \& Liu, Q. (2010). Composition, molecular structure, properties, and modification of pulse starches: a review. Food Research International, 43(2), 399-413.

Messina, M. J. (1999). Legumes and soybeans: overview of their nutritional profiles and health effects. The American Journal of Clinical Nutrition, $70(3), 439 \mathrm{~s}-450 \mathrm{~s}$.

Pelgrom, P. J. M., Vissers, A. M., Boom, R. M., \& Schutyser, M. A. I. (2013). Dry fractionation for production of functional Pea protein concentrates. Food Research International, 53(1), 232-239.

Pelgrom, P.J.M., Berghout, J.A.M., van der Goot, A., Boomm R.M., \& Schutyser, M.A.I. (2014). Preparation of functional lupine protein fractions by dry separation. LWT - Food Science and Technology.

Pelgrom, P. J. M., Boom, R. M., \& Schutyser, M. A. I. (2015a). Functional analysis of mildly refined fractions from yellow pea. Food Hydrocolloids, 44, 12-22.

Pelgrom, P.J.M., Boom, R.M. \& Schutyser, M.A.I. (2015b). Pre- and post-treatment enhance the protein enrichment from milling and air classification of legumes. 
Pernollet, J. C. (1978). Protein bodies of seeds: ultrastructure, biochemistry, biosynthesis and degradation. Phytochemistry, 17(9), 14731480.

Plant, A. R., \& Moore, K. G. (1983). The protein, lipid and carbohydrate composition of protein bodies from Lupinus angustifolius seeds. Phytochemistry, 22(11), 2359-2363.

Reichtert, R. D. (1982). Air classification of peas (pisum sativum) varying widely in protein content. Journal of Food Science, 47, 12631267.

Schutyser, M. A. I., \& Van der Goot, A. J. (2011). The potential of dry fractionation processes for sustainable plant protein production. Trends in Food Science \& Technology, 22(4), 154-164.

Sosulski, F., \& Youngs, C. G. (1979). Yield and functional properties of Air-classified protein and starch fractions from eight legume flours. Journal of the American Oil Chemists Society, 56, 292-295.
Tyler, R. T. (1984). Impact milling quality of grain legumes. Journal of Food Science, 49, 925-930.

Tyler, R. T., Youngs, C. G., \& Sosulski, F. W. (1981). Air classification of legumes [beans, lentils, peas]. I. Separation efficiency, yield, and composition of the starch and protein fractions. Cereal Chemistry, 58(2), 144-148.

Weber, E., \& Neumann, D. (1980). Protein bodies, storage organelles in plant seeds. Biochemie und Physiologie der Pflanzen, 175(4), 279-306.

Wood, J. A., Knights, E. J., Campbell, G. M., \& Choct, M. (2014). Differences between easy-and difficult-to-mill chickpea (cicer arietinum L.) genotypes. Part I: broad chemical composition. Journal of the Science of Food and Agriculture, 94(7), 1437-1445.

Wu, Y. V., \& Stringfellow, A. C. (1992). Air classification of flours from wheats with varying hardness: protein shifts. Cereal Chemistry, 69(2), 188-191. 